\title{
Philippines: \\ Factors of Century-Old Conflict \\ and Current Violent Extremism in the South
}

\author{
Primitivo Cabanes RAGANDANG III
}

\begin{abstract}
The perpetual struggle for separatism among Moros in Mindanao is produced on a background of historical and cultural injustices and by the presence of Moro liberation fronts, along with the government responses to this issue. This article endeavors to trace and interweave the roots of historical and cultural factors of Muslim separatism in Mindanao, along with its implication to the present Marawi crisis as fueled by the ISIS-linked groups who attacked the Philippines' Islamic city on May 23, 2017. It looks into the history of the arrival of Islam and the subsequent islamization of Mindanao. It then discusses the Muslim resistance movement against two foreign regimes, Spanish and American, which is followed by its resistance against the Philippine government. Factors that trigger Muslims' desire for separatism include at least three notorious massacres: Jabidah, Manili, and the Tacub Massacre. Such historical factors of injustices have fuelled the century-old struggle for separatism and self-determination. With the government's and non-government forces' failure to pacify the island, such struggle resulted into continuing war in the region killing over 120,000 Mindanaoans. Recently, this conflict in the region was reignited when an ISIS-linked group attacked the Philippines' Islamic city of Marawi, affecting over 84,000 internally displaced persons from over 18,000 families who are now seeking refuge in 70 different evacuation centers, in a state of discomfort, missing home and psychologically distress.
\end{abstract}

Keywords: Marawi, Mindanao, Muslim, Philippines, separatism, violent extremism.

Primitivo Cabanes RAGANDANG III

Faculty, Political Science Department

Mindanao State University-lligan

Institute of Technology

E-mail: prime.tivo@gmail.com

Conflict Studies Quarterly

Issue 22, January 2018, pp. 81-94

DOI:10.24193/csq.22.5

Published First Online: 01/10/2018

\section{Introduction}

In one interfaith forum attended by leaders and peace advocates of various religious faith around Mindanao, one member of the Moro Islamic Liberation Front (MILF) stood 81-94and said,

Klaro kayo nga sa atong kasaysayan wa gyud masakop ang mga Muslim; 
unya isagol na hinoon mi sa Pilipinas? Dili kami mga Pilipino, mga Muslim kami! (It is clear in our history that Muslims were never conquered; and why integrate us in the Republic of the Philippines? We are not Filipinos, we are Muslims!)

The issue of Muslim separatism in Mindanao is not a recent one; it originated as early as the beginning of $18^{\text {th }}$ century during the Spanish colonization - accidents in political history that placed the hitherto autonomous Muslim communities under alien rule (Che Man, 1990). However, the intensity of the issue in the contemporary period is as intense as it was before. As a matter of fact, Dacobor of the Mindanaw Tripartite Youth Core (2008, personal communication) commented that "every time topics in peace forum reach to the issue on Muslim Separatism, it is not uncommon that the conversation will end up a serious and intense one".

Geographically known as the second biggest island of the Philippine archipelago, Mindanao is now home to three major ethno-linguistic groups, namely: the lumads (indigenous peoples), Christian settlers, and the Muslim community (AFRIM Resource Center, 1980). Also referred to as Moros, the Muslim community in Mindanao is divided into 13 different ethnic groups which are all tied by their religion of Islam. As cited by Che Man (1990), De Vos and Romanucci-Ross (1975) and Hall (1979) defined ethnic community as "a self- perceived group of people who hold in common a set of traditions not shared by the other with whom they are in contact". This definition assumes that for an ethnic group to emerge, there must be some 'primordial' ties around which to build a sense of community. These primordial ties include such traditions as common myth of descent or place of origin, sense of historical continuity and distinct cultural practices (Che Man, 1990).

In line with this, the Muslim community in Southern Philippines does not lack any of these 'primordial ties' that enable them to emerge. As a matter of fact, the Muslims in the Philippines are known for their very rich culture that is still evident to these days. Their community is well bounded by the strong foundation that ties them - their religion, Islam. With this, it is evident that their fearless, bloody and determined struggle for separation never weakens because of the influence of their religion. They are determined that Allah is with them and shall keep His promises. As what Allah revealed to Prophet Muhammad (SAW) as indicated in Qur'an II: 190 "whosoever fight for the sake of Allah, shall inherit the paradise that Allah prepared for them".

\section{Mindanao as the Homeland of Muslims Filipinos}

Mindanao is a variant of the name "Maguindanao" which means 'inundation by river, lake or sea'. The region comprises of the principal island of Mindanao and a chain of some 369 smaller islands of the Sulu archipelago and is about 96,438 sq.km. in area (Che Man, 1990). The geographical characteristics of Mindanao, being at the Southern part of the Philippine archipelago, consequently makes it near to the Malay World. That 
is a substantial factor which made Mindanao the most Islamized island throughout the archipelago. Islam is one of the oldest organized religions established in the Philippines. Its origins in the country may be traced back as early as to the 14th century, with the arrival of Arab and Malay Muslim traders who converted some of the native inhabitants in the southwestern Philippine Islands (Gowing, 1988). Islam is the Philippines' second largest religion, with 5,127,084 followers as of 2010 (Bueza, 2015).

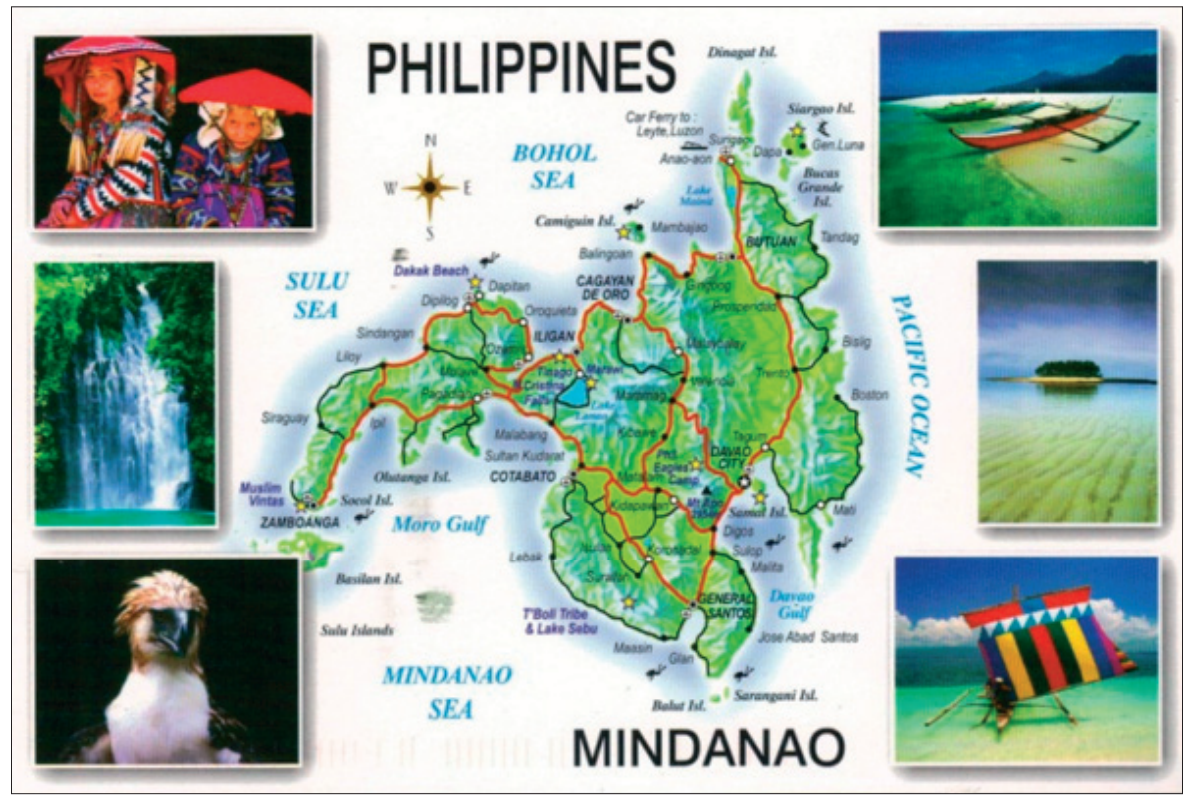

Figure 1. Map of Mindanao, the second biggest island, located in Southern Philippines

Representing less than 15 percent of the population of the Philippines (the only predominately Christian country in Southeast Asia), Filipino Muslims are geographically concentrated in the South of the country in Mindanao and Sulu and are distinguished from Christian Filipinos not only by their confession of Islam but also by their evasion of over 300 years of Spanish colonial domination. In addition, these Filipino Muslims themselves have always been separated from one another in this archipelagic nation by significant linguistic and geographic distance intothree major and ten minor ethno-linguistic groups who are dispersed across southern Philippines. The three largest ethno-linguistic groups are the Maguindanaons of the Pulangi river basin of central Mindanao, the Maranaos of the Lanao Lake region of central Mindanao and the Tausugs of Jolo island in the Sulu archipelago. Smaller groups include the Yakans of Basilan Island, the Samals of the TawiTawi island group in Sulu and the Iranuns of the Cotabato coast of Mindanao. In some parts of their traditional territory, Philippine Muslim population retains its majority; about 98 per cent of the populations of the Sulu archipelago, for example, are Muslims. 
In Mindanao-Sulu as a whole, however, Philippine Muslims now comprise less than 17 per cent of the population, due primarily to large scale Christian immigration from the north over the past 60 years (National Commission on Muslim Filipinos, 2016).

Philippine Muslims share their religious culture with the neighboring Muslim-majority nations of Indonesia and Malaysia. They also retain certain elements of an indigenous pre-Islamic and precolonial lowland Philippine culture (expressed in dress, music, political traditions and a rich array of folk beliefs and practices) that are similar to those found elsewhere in island Southeast Asia, but are today mostly absent among Christian Filipinos. Thus, while Philippine Christians and Muslims inhabit the same state and are linked together by various attachments, a profound cultural gulf created by historical circumstance separates them. That gulf is the outcome of two interlinked events; the conversion of some regions of the Philippines to Islam and the Spanish colonial occupation of other regions shortly afterward. Islamization was still underway in the archipelago when the Spaniards gained their foothold in the Northern Philippines in 1571. After consolidating control of the Northern tier of the Philippine islands, they failed, despite repeated attempts, to subdue the well-organized Muslim sultanates of the South.

The Spaniards assigned to the unsubjugated Muslim peoples of the southern sultanates the label previously bestowed on their familiar Muslim enemies from Mauritania and Morocco, "Moros" (Moors). The term "Moro" was applied categorically and pejoratively with scant attention paid to linguistic or political distinctions among various "Moro" societies. The American colonizers who succeeded the Spaniards and eventually subdued Philippine Muslims in the early twentieth century by means of overwhelming force, continued the usage of "Moro" even though it had become pejorative among Christian Filipinos, denoting savages and pirates. In a bold semantic shift, Philippine Muslim separatists during the late 1960s appropriated the term "Moro" and transformed it into a positive symbol of collective identity, one that denominated the citizens of their newly imagined nation. For more than 30 years, Moro activists have sought self-determination for Philippine Muslims, sometimes through armed struggle. Their efforts have caused the Philippine state to experiment with regional autonomy for the Muslim South and have conditioned state responses to the claims of other unhispanized minorities.

Fox and Flory (as cited by Gowing, 1980) identified cultural-linguistics who are of Muslim denomination, though a few of the groups, such as the Badjao of Sulu, have been less intensively Islamized. These thirteen Moro groups, mainly found in the Cotabato region, Sulu archipelago and Lanao region, do speak various dialects (often the name of the group and the name of the language being the same) (Gowing, 1980). Moreover, Moro groups differ ${ }^{1}$ to some extent in their historical development and in the intensity of their contacts. They also differ in the details of their social organization; in the degree of their Islamic acculturation; and in their dress, customs, arts and many other aspects of culture (Gowing, 1980). 
The Islamization in the southern Philippines occurred along with the Islamization of Borneo Sulawesi, Celebes and the Moluccas island of Indonesia. It is likely that Muslim Arab traders had begun trading in the Philippines long before the Filipinos started to embrace Islam. Scholars today believe that Muslim merchants, trading profitably in the Malay world, brought Borneo to the attention of the Chinese during the tenth century. Further, he also points to a venerated grave of a foreign Muslim (possibly an Arab), which is found in a tempat (sacred grave) on Bud Dato, a few miles from Jolo town. Moreover, the genealogy of Sulu speak of a foreigner who bore a title Tuan Mashai'ka and who came to Jolo long ago, married to a daughter of a local chieftain and begot Muslims- meaning that he raised his children as Muslims. Another genealogy that Tuan Mashai'ka came when the people of Jolo were still worshipping stones and other inanimate objects. Thus, Islamization, the process of Islam taking root among the people outlive to Sulu, may will have begun to Tuan Mashai'ka who raised Muslim children with his wife (Gowing, 1980).

More so, Gowing (1980) argued that the genealogies of Sulu were not written as scientific histories of the archipelago's chief families, as documents of their time and space. Rather they contain elements that are mythological and baffling for the present generation. Even so, they are important sources for clues as to the beginning of Islam in the Philippines. Furthermore, the Sulu traditions speak also of Rajah Baguinda, who late in the fourteenth or early fifteenth century came to Jolo from the Menangkabaw region of Sumatra at the head of a small fleet of praus (sail craft) transporting a force of warriors and settlers. Other than this, more traditions speak of an Arab, Sayyid Abu Bakr, who came to Buansa towards the middle of the fifteen-century and lived with Rajah Baguinda. He married the old Rajah's daughter, Paramisuli. After the death of his father in law, Sayyid Abu Bakr succeeded to the latter's political authority and eventually founded the Sultanate of Sulu (Gowing, 1980).

\section{The Muslim Resistance Movements}

Like other early Filipinos settlements, the Moros in Mindanao lived harmoniously and independently before the advent of foreign invaders. However, the coming of the colonizers disturbed their peaceful living, and so resistance followed. The Islam religion, their unifying element, made their resistance stronger compared to any other early settlements that had resisted. This is evidence for the fact that, among other things, Spaniards found it difficult to colonize and Christianize them.

As Majul (1999) puts it, the Spanish colonization in the Philippines can be summarized under the headings of God, Glory, and Gold. The kind of colonial system Spain established in the Philippines depended of the broad aim for Spanish colonialism. More resistance against Spain began in $16^{\text {th }}$ century when Spain established her sovereignty in Visayas and Luzon and then sought to extend it to Mindanao and Sulu as well. Unfortunately, the 
Moros responded to such intentions with violence and warfare. As a matter of fact, Jolo alone was attacked 16 times. Yet, the plan to "Hispanize and Christianize the Moros", one of the four laid plans of the Spanish Moro Policies, has never been realized. This drove Gen. Luis de la Torre, a Spanish officer, to write to the governor general of the Philippines: "The Moro race is completely antithetic to the Spanish ... and will ever be our enemy" (Majul, 1999). Evidently, the Moros responded to such designs with violence and warfare. Moro buccaneers harassed Spanish ships and so were deemedpirates. Moro expeditions carried Jihad to the coast of Visayas and Luzon where their war vessels periodically raided, killed and plundered Christian settlements (Majul, 1999).

In August 1898, when Spain raised their white flag, as Agoncillo (1990) puts it, the Americans successfully took over the administration of the Philippines. Consequently, the American administration of the Moro land, which was developed in three successive stages, took place between 1899 and 1920. In 1899, there was an initial MuslimAmerican contact and military occupation of the Moro land, which ended in July 1903 upon the inauguration of the Moro Province. Next a decade of establishment of the Moro Province (1903-1913) followed which exercised politico-military control over the region and prepared Muslims for a civil government. Finally, a six-year period (19141920) of bringing Mindanao and Sulu into the general governmental framework of the Philippines followed.

Nevertheless, this transfer of sovereignty over Moro land from Spain to the United States of America did not render the Moros less vigorous in their resistance to colonialism. Thousands of them fought and died resisting the American policy of incorporating their homeland into the Philippine state (Che Man, 1990). Act Number 2878 of the Philippine Legislature formally abolished the Department of the Interior, exercising its power through the Bureau of Non-Christian Tribes (Che Man, 1990). Though American officials continued to play important roles in administering the affairs of the Moros, the region was now largely under the control of Christian Filipinos.

However, Thomas (1971, as cited by Gowing, 1980) argued that the Moros believed that the Christian Filipinos, influenced by centuries of Spanish domination, had hidden motives to stamp out their religion and traditions. As a result, Moro leaders in Sulu presented a petition to the president of the United States requesting that Sulu be governed separately from the rest of the Philippines. Yet, their petition went unheeded. Thus, Moro and Filipino communities were incorporated (Gowing, 1979).To this end, Moros expressed their discontent through armed resistance, though they no longer had the strength to represent the same threat they did to the Americans up to 1913 (Tan, 1977, as cited by Gowing, 1979).

After decades of resisting the American efforts to include their homeland in the Philippines, some Moro leaders realized that their resistance was pointless (Che Man, 1990). Moro land was structurally integrated into the Republic of the Philippines which 
was proclaimed on July 04,1946 . There were development efforts laid down by the national government to Mindanao, however, only Christian settlers and foreign entrepreneurs benefited from it (Gowing, 1979). As a result, some Moros expressed their discontent towards the government through armed struggle again.

\section{Factors leading to the Muslim Separatism}

The Moro resistance ended-up becoming a full-fledged and organized Moro separatist movement. Muslim separatism intended the preservation of the Muslim community which was possible only through its separation from the Philippines. The Moros pursued their separation during the administration of Ferdinand Marcos from1965 until 1986. There were significant events that led to the formation of Separatist Movements.

\section{The 1968 Jabidah Massacre}

Details of the Jabidah Massacre are less clear because of conflicting reports. However, between 28 and 64 Moro recruits out of a large number undergoing guerilla warfare training in Corregidor Island were massacred in late March 1968 by the Philippine Army men. The training was allegedly in secret preparation for Philippine military operations in Sabah-code-named "Operation Merdeka". Operation Merdeka, as explained by some Moros, was an attempt by the Philippine government to split Islamic ranks and provoke a war between Sulu and Sabah. The cause of the execution was never made public by the Philippine government. Jubair (1984, as cited by Che Man, 1990) mentioned that according to the lone survivor, Jibin Arola, the "trainees were shot because they refused to follow the order to attack Sabah". Aware of the possible impact of the leakage of this secret plan, the military authorities executed the entire company so that no one survived to tell the story (Jubair, 1984). Further, Noble (1983) pointed out that the Jabidah Massacre had two important political consequences. First, the Moros were angered at the disregard for their lives shown by the Marcos government. Secondly, it inflamed the Malaysian Government of Tunku Abdul Rahman, which, having made compromises to Marcos' desire to establish diplomatic relations, saw itself "stabbed in the back by the Philippines" (Che Man, 1990).

Two months after the Jabidah accident, Datu Udtog Matalam founded the Muslim Independence Movement (MIM) which the Malaysian government supported (Lucman, 1982). In 1969, the first group of young Moros (comprising of 67 Maranaos, 8 Maguindanaons, and 15 Suluanos) was sent to Malaysia for military training (Che Man, 1990).

From mid-1970 to 1971, a conflict between Muslims and Christians began to erupt in Lanao del Norte, Cotabato and Lanao del Sur. The Muslim groups, identified as Barracudas and Blackshirts, were allegedly linked to Congressman Ali Dimaporo in Lanao del Norte and tothe MIM in Cotabato, respectively. The Christian groups, known 
as 'Ilagas' ('rats'), were allegedly linked to Congressman Arsenio Quibranza of Lanao del Norte and tollonggo settlers, Tiruray tribal people and constabulary units in Cotabato. By the end of 1970, fighting between these two rival groups had resulted in many casualties, disruption of the economy, and mass evacuation. More than 30,000 Muslims, Christians, and Tirurays had been forced to leave their farms (Che Man, 1990).

\section{The Manili Massacre of 1971}

The most publicized incident after the Jabidah Massacre was the Manili Massacre. It occurred in June 1971when about 65 Muslims - men, women, and children - were murdered by Ilagas at a mosque in Barrio Manili, North Cotabato (Gowing, 1979). On the part of the Muslims, the Manili incident carried a special weight because it took place in a compounded mosque. It was seen as an act of religious humiliation. In line with this, Ali Treki of Libya (1972, as cited by Che Man, 1990) believed that the conflict became a religious war. When the late Libyan Information and Foreign Minister, Saleh Bouyasser, was informed about the killings of the Muslims during his visit to the Philippines in 1971, he took the initiative to talk with the Moro leaders. It was as a result of this meeting that, on the one hand, Bouyasser recommended to his government that it should help the Moro people and, on the other hand, a declaration of unity was signed among different groups of Muslim leaders. Cries of 'genocide' began to be heard from the Moro leaders.

\section{The Tacub Massacre and the Election of 1971}

During the 1971 elections for the Constitutional Convention, there was a bitter rivalry between a Muslim Congressman and a Christian Governor in Lanao Del Norte. This rivalry developed quickly into a poll battle dividing Muslims and Christians (Gowing, 1979). As a result, a special election had to be scheduled. On the day of the special elections, a group of unarmed Moro voters were fired upon by the government troops in Barrio Tacub in the municipality of Kauswagan, Lanao Del Norte. About forty Moros were killed with no fatality on the government side (Gowing, 1979).

Investigation by the National Bureau of Investigation resulted in charges of multiple homicides being brought against 21 army men and three civilians. Muslim leaders counseled patience to allow the law to take its course, but by March of 1972, the charges against the civilians and against five of the soldiers were dropped "for lack of evidence". The disposition of the case against the remaining 16 soldiers was never reported-presumably the case was quietly dropped, a practice not uncommon with cases in which the victims are Moros (Gowing, 1979).

With such events during the 1971 elections, Noble (1976, as cited by Gowing, 1979) stressed that it stimulated the rise and activity of rival Muslim and Christian groups, escalated the level of violence and attracted the attention of Muslim state abroad. By the end of 1971, the Mindanao insurgency had taken a toll of 800 lives and over 100,000 
refugees. In 1972, the conflict spread to Zamboanga del Sur, where Ilaga bands appeared, and to Balabagan near Malabang in Lanao del Sur, which have a mixed Muslim-Christian population.

\section{Moro Liberation Fronts and the Government Responses}

The uncertainty and fears generated in the aftermath of the Jabidah Massacre in 1968 created a new urge among the Moros to search for alternatives to secure the Ummah (or the community of faith). To the Moros, the Filipino Christian Government had proved to be insensitive to their demands and unwilling to ensure protection of their lives (Asani, 1985, as cited by Che Man, 1990). More so, this period saw Muslim youth and student activists beginning to assert their demands for better treatment of the Moro people. As a result, several Moro liberation fronts emerged.

According to Che Man (1990), there exist five Moro underground groups in Southern Philippines by 1990. These were the Misuari and Pundatu factions of the Moro National Liberation Front (MNLF), the Bangsa Moro Liberation Organization (BMLO), which was latter change into as the Bangsa Muslimin Islamic Liberation Organization (BMILO), the Moro Islamic Liberation Front (MILF) and the Moro Revolutionary Organization (MORO).

Unfortunately, these liberation fronts do not exist anymore, except for the $\mathrm{MILF}^{2}$ which is still operating mainly in the Cotabato region. Further, Since September 11, 2001, however, the Muslim struggle for autonomy has been recast as part of the War on Terror, politicizing international interest and overshadowing humanitarian concerns. As a result, the needs of at least 100,000 refugees and displaced persons from the region have been largely ignored.

While there is no question that Muslim extremists have found a haven in the Southern Philippines, the conflict in Mindanao reflects long-standing tensions between local movements advocating for political autonomy and the central government, which represents the outlook of the Catholic majority of the country. The situation in the southern Philippines is a classic case of humanitarian concerns and consequences being ignored in the context of violent political conflict exacerbated by external forces.

Later on, the Philippine government faced a bloody battle against another liberation front: the Abu Sayyaf. ${ }^{3}$ The Abu Sayyaf Group, also known as al-Harakat al-Islamiyya, is one of several militant Islamist separatist groups based in and around the Southern islands of the Philippines, particularly in Jolo and Basilan, where for almost 30 years various groups have been engaged in an insurgency for an Islamic state, independent of the predominantly Christian Philippines. Hostilities broke out again in Basilan's AlBarka town in July this year after MILF fighters attacked government forces and killed 14 soldiers who strayed into a rebel stronghold while pursuing the Abu Sayyaf. The Abu Sayyaf later beheaded ten of the soldiers as they retreated (History Commons, 2007). 
Since 2002, the Philippine offensive against Abu Sayyaf became more intense and effective on Basilan and Jolo islands, with many of its members killed and captured. However, the Abu Sayyaf has established links with the Indonesian terror group, Jemaah Islamiah, and a local radical organization called the Rajah Soliman Movement, which is made up of Filipinos who converted to Islam. The MILF has repeatedly denied any links with JI, although military commanders say there is a connection between the two groups. They say JI militants - among them Indonesian bombers Dulmatin and Umar Patek and Malaysian Zulkifli bin Hir, who heads the Kumpulun Mujahidin Malaysia (KMM) terrorist organization - provided the MILF and Abu Sayyaf training on explosives (Jacinto, 2007).

Former Philippine President Arroyo ordered the Armed Forces to crush insurgencies in the three years before her she steps down by 2010. But it was a tall order and is unlikely that the military will be able to wipe out the Abu Sayyaf, or the leftist New People's Army. New breeds of insurgents and terrorists, deadlier and smarter, will come and go and leave their marks in strife-scarred Mindanao, despite the so-called war on terror, unless poverty and corruption in the government are eliminated and eventually peace will reign (Jacinto, 2007). The Philippine branch of the International Islamic Relief Organization (IIRO) was founded in 1991 by Khalifa. This former member, who uses the alias "Abu Anzar", says the IIRO continues to fund the Abu Sayyaf after Khalifa's arrest in the US in late 1994. In 2006, the U.S. Government officially lists the Philippine IIRO branch as a terrorism financier and state that it is still being run by one of Khalifa's associates (The Globetrotter, 2007).

Armed separatist mobilization is the price the Philippine government continues to pay for its past mistakes (and those of its colonial predecessors) in Muslim Mindanao. By marginalizing Philippine Muslims in their own homeland through massive governmentsponsored immigration, the government created a relatively impoverished regional minority resentful of the benefits provided to Christian migrants and highly suspicious of government motives. Even so, the Muslim separatist rebellion begun in 1972 was by no means inevitable. It was the highly aggressive actions of the martial law regime that transformed Muslim suspicion into organized armed antagonism toward the central state. Armed separatist resistance, and the international support it attracted, led to the signing of the Tripoli Agreement and it is continued armed resistance (actual or threatened) that has brought about all subsequent autonomy agreements, including the most recent. It is difficult or impossible to imagine any government offer of Muslim autonomy without the armed challenge (Araneta, 1999).

The Philippine government has thus found itself caught between its desire to end a costly armed separatist challenge that has proved impervious to military suppression and the significant pressures placed upon it by various interest groups, especially Mindanao Christians, not to make any substantive concessions to Muslim separatists. This has resulted in the creation of a succession of formally autonomous entities that are extremely 
limited in both their power and scope. It has also caused the Philippine government to ignore to the greatest extent possible the MILF, the Muslim separatist front based in Central Mindanao and operating most closely to concentrations of Christian population. Since 1987, the MILF has engaged in offensive action only to force the government to the negotiating table with a show of its armed capacity. In 1987 it turned to offensive armed action after a peaceful mass demonstration in Cotabato City drew absolutely no government response. It is likely also that the MILF changed its announced goals from its original demand from autonomy to a call for a separate state primarily to gain the government's attention. If the experience of the past 28 years of armed conflict in Muslim Mindanao teaches anything, it is that the current administration's "get tough" policy will have the opposite of its intended effect. It will energize the MILF and increase its popular support while undermining what is left of the 1996 Peace Agreement. There is an untried alternative to an attempted military solution to the continued armed separatist challenge in Muslim Mindanao - genuine regional development. After more than 25 years of Philippine government claims to be "developing" Muslim Mindanao, recent national statistics illustrate the sad reality (Jacinto, 2007).

In virtually all measures of physical and economic well-being, the Autonomous Region for Muslim Mindanao (ARMM) is found at or near the bottom of the national rankings (National Statistics Office, 2008). In government-supplied services ranging from access to prenatal care to availability of college scholarships for low-income students, ARMM ranks last (National Statistics Office, 2000). As found with separatist movements elsewhere, ordinary Philippine Muslims are most likely to fight for or support an armed separatist front when they perceive no alternative means to overcome discrimination and better their living conditions. Rather than empty autonomy arrangements or further military offensives, the Philippine government might substitute a genuine commitment to both protect the cultural heritage of Philippine Muslims and provide them with tangible means to improve their livelihood. Those provisions are, after all, what Philippine Muslims most require from the Philippine government.

\section{Beyond Muslim Separatism: ISIS-Linked Maute Group attack in Marawi City}

The battle for Marawi began on May 23, 2017 when the Philippine military tried to capture Isnilon Hapilon, the head of a Southern militia that has pledged loyalty to ISIS leader Abu Bakr al-Baghdadi. But the army met an unexpectedly fierce resistance. Allied with another pro-ISIS brigade called the Maute Group, Hapilon's fighters took a priest and his congregation hostage, freed prisoners from the local jail and overran the city. More than four months later, the fighting persists, hundreds have died - militants, soldiers, civilians - and hundreds more residents remain trapped in the city. Many have no electricity or running water. Food stocks are diminishing fast. As residents seek safety, much of Marawi has become a ghost town (Hincks, 2017). 


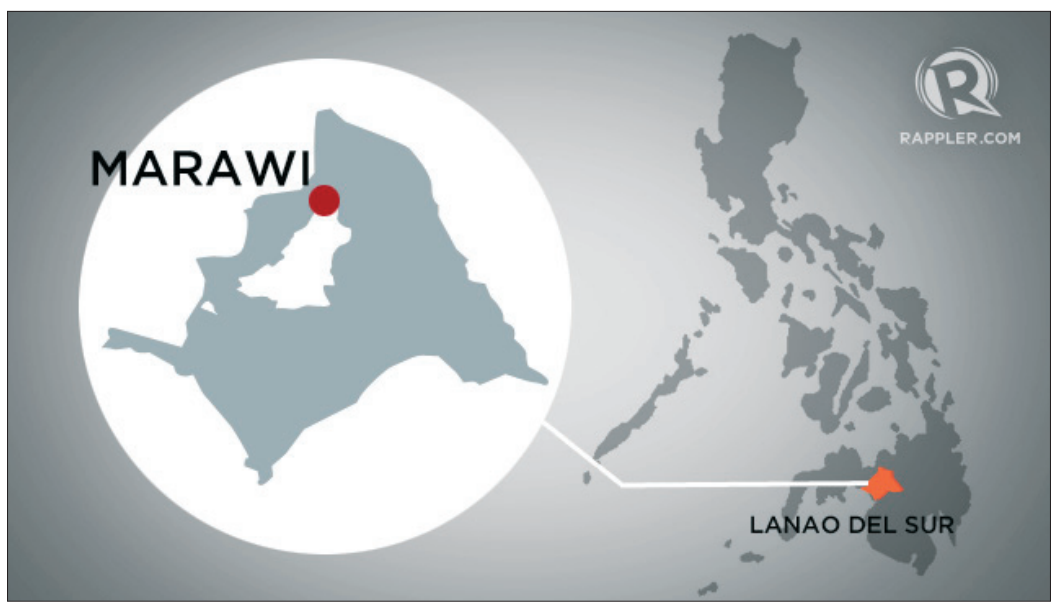

Figure 2. Map of Marawi City, also known as the Islamic City of the Philippines Adapted from: Rappler (2017).

Marawi is the latest front in what has been a recent surge of apparently ISIS-linked attacks beyond the carnage in Iraq and Syria. These include: a bloody late May assault on Coptic Christian pilgrims in Egypt, the suicide bomber at the Ariana Grande concert in Manchester, the London Bridge assailants the following week, twin suicide bomb attacks that killed three policemen in Jakarta and twin attacks in Tehran. For now that struggle revolves around Marawi and Mindanao. Nearly 200 families were squeezed into Iligan's rapidly repurposed Buru-un evacuation center. Some occupied squares of floor space partitioned by wooden slats and shared with bags, cardboard boxes, and Tupperware containers of milk powder. Others spilled onto an adjacent sports field or baked under the tarp of U.N. tents. Two weeks earlier, this center had been a school assembly hall, says camp manager Eva Dela Cruz. It isn't clear where these families will, or can, go when classes restart. While the Marawi militants have targeted Christians, as elsewhere in the world, the majority of victims of the Islamist terrorism are Muslims who reject violence. Tens of thousands of inhabitants have been forced to flee since the fighting broke out.

If the history of Mindanao conflict revolved around religion and the quest of self-determination, this has not been the case of the recent violent attack by the ISIS-linked Maute Group. Though the attacks are spearheaded by a group of Islam believers, victims are no longer non-Muslims alone. As a matter of fact, more than $80 \%$ of the victims of the current crisis are Muslims from Marawi City, majority of which belongs to Maranao tribe. Thus, the present situation of the long evolution of century-old conflict in Mindanao has no longer been characterized as a religious rivalry or an attack to a cultural minority. Efforts to rehabilitate the city and help the internally displaced persons (IDPs) are done hand-in-hand by people from various socio-cultural and religious backgrounds. 
With such, this implies that while the current conflict is a manifestation of religious extremism, it is not directly connected to the historical fuels of Mindanao conflict. It is also good to emphasize that while efforts for self-determination and Muslim separatism have not ended, the current situation is not a link that binds the efforts Muslim Filipinos wanting to separate from the Republic of the Philippines.

\section{Conclusion}

This research has presented information about the nature of Muslim separatism in Mindanao, which became a perpetual struggle among the Moros. Such struggle has marked the history of the Moro people and left in delible ink in the heart of every Moros.

It has also presented the historical background of the Moros in the Philippines, their ethnicity and the long process of the coming and penetration of Islam religion in Mindanao. It also enumerated the series of Muslim resistance against the foreign rules of incorporating them into the Philippines, viz: the Jabidah Massacre in 1968, Manili Massacre in 1971, Tacub Massacre and the election in 1971. The essence of the study is that it has presented different factors which ignite the Moro people to fight for separation from the Philippines. It includes also the government responses to the Moro Liberation Fronts that was become rampant during the Marcos administration. The advocacy for separatism continues. What perhaps distinguishes Muslim separatist Movements from the rest is that they have integrated Islamic concepts and symbols into a national dogma and that Islam and nationalism reinforced each other against foreign rulers, while at the time linking them with the wider Islamic ummah.

\section{Notes:}

1 Gowing (1980) argued that such differences should not be emphasized as to lose sight of the things they have in common, which justify their being included together under the general name "Moro" or " Muslim Filipino".

2 As a matter of fact, the author had attended an Inter Faith Youth Exchange Camp at the Shariff Kabungsuan Province in which the organizer of the said activity was the Moro Islamic Liberation Front (MILF), financed by an Australia-based philanthropic institution.

3 The name of the group is derived from the Arabic "abu" (meaning, "father of") and "sayyaf" (meaning, "Swordsmith"). Since its inception in the early 1990s, the group has carried out bombings, assassinations, kidnappings, and extortion in their fight for an independent Islamic state in western Mindanao and the Sulu Archipelago with the stated goal of creating a pan-Islamic superstate across southeast Asia, spanning from east to west; the island of Mindanao, the Sulu Archipelago, the island of Borneo (Malaysia, Indonesia), the South China Sea, and the Malay Peninsula (Peninsular Malaysia, Thailand and Myanmar). The U.S. Department of State has branded the group a terrorist entity by adding it to the list of Foreign Terrorist Organizations (Asiaweek, 1999).

\section{References:}

1. AFRIM Resource Center. (1980). Mindanao report: a preliminary study on the economic origins of social unrest. Davao City: AFRIM Resource Center. 
2. Agoncillo, T. A. (1990). History of the Filipino people ( $8^{\text {th }}$ ed.). Quezon City: Garotech Publishing.

3. Araneta, S. (1999). Reform in the Philippines. Manila: Bayanikasan Research Foundation.

4. Bueza, M. (2015). MAP: Islam in the Philippines. Rappler. Retrieved from: www.rappler. com/newsbreak/iq/99572-map-islam-philippines.

5. Che Man, W. K. (1990). Muslim separatism. Quezon City: Ateneo de ManilaUniversity Press.

6. De Vos, G., \& Romanucci-Ross, L. (1975). Ethnic identity: cultural continuities and change. California: Mayfield Publishing Company.

7. Gowing, P. G. (1980). Muslim Filipinos: heritage and horizon. Quezon City: New Day Publishers.

8. Gowing, P. G. (1988). Understanding Islam and Muslims in the Philippines. Quezon City: New Day Publishers.

9. Hall, R. L. (1979). Ethnic autonomy--comparative dynamics: the Americas, Europe and the developing world. New York: Pergamon Press.

10. Hincks, J. (2017, October 16). What the siege of a Philippine city reveals about ISIS' deadly new front in Asia. Time. Retrieved from: http://time.com/marawi-philippinesisis/.

11. History Commons. (2007, October 3). Abu Sayyaf profile. History Commons. Retrieved from www.cooperativeresearch.org=abu_sayyaf.

12. Jubair, S. (1999). Bangsa Moro: a nation under endless tyranny. Kuala Lumpur, Malaysia: IQ Marin.

13. Jacinto, A. (2007, September 15). War in the southern Philippines. The Manila Times. Retrieved from www.manilatimes.net/national/2007/sept/11/yehey/top_stories/.

14. Lucman, S. H. (1982). The Chairman's Message to the Bangsa Moro People for Unity. Cotabato City: Bangsa Moro Liberation Organization.

15. Majul, C. A. (1999). Muslims in the Philippines ( $3^{\text {rd }}$ ed.). Quezon City: University of the Philippines Press.

16. National Statistics Office. (2008, December 1). Muslims in the Philippines. E-Census. Philipine Statistics Authority. Retrieved from www.ecensus.com.ph/Default.aspx.

17. Rappler (2017, October 16). Map of Marawi city. Rappler. Retrieved from www.rappler. com/previous-articles?filterMeta=Marawi\%20Map. 